
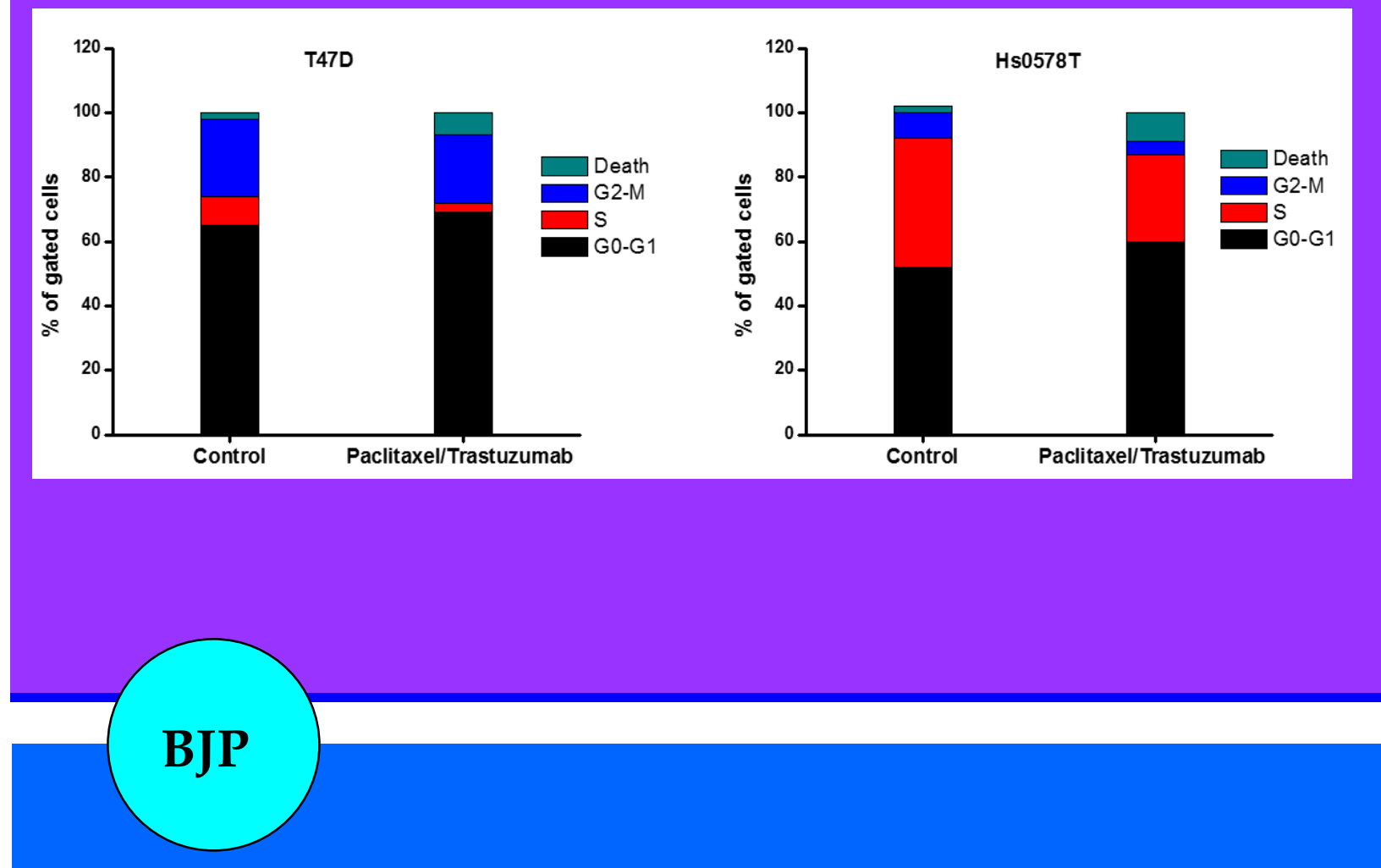

Bangladesh Journal of Pharmacology

Research Article

\title{
Paclitaxel and trastuzumab treatment affects insulin growth factor I expres- sion in breast cancer cell lines
}




\title{
Paclitaxel and trastuzumab treatment affects insulin growth factor I expression in breast cancer cell lines
}

\author{
Yu-Xian Qian', Rui Yu² and Shi-Rong Qin'1 \\ ${ }^{1}$ Department of General Surgery, Ningbo Longsai Hospital, Zhejiang Province, 315 200, China; ${ }^{2}$ Medical School, \\ Ningbo University, Ningbo City, Zhejiang Province, 315 211, China.
}

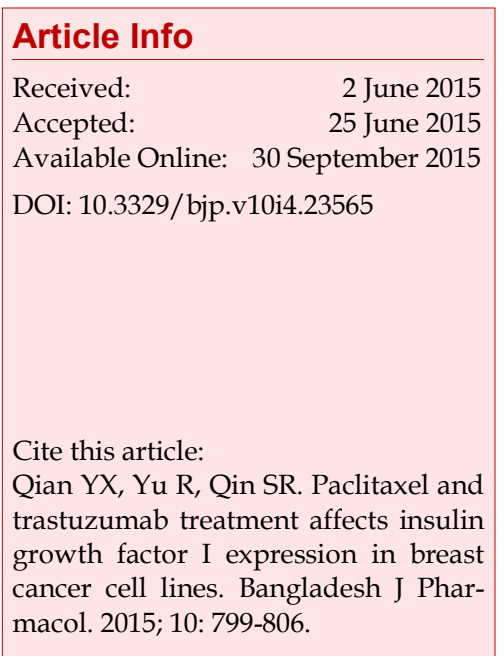

\section{Introduction}

Insulin-like growth factor I receptor (IGF-1R) is a receptor tyrosine kinase (RTK) protein overexpressed (about $70 \%$ ) in breast cancer cells (Nielson et al., 2004; Sachdev et al., 2004). IGF-1R plays an essential role growth and maintenance of cancer cells and found to be a target for cancer treatment. IGF-1R is one of such receptors which consists of two a-subunits involved in ligand binding outside the cell and two $\beta$-subunits with a tyrosine kinase, TM domain and carboxyl terminal domain (Ullrich et al., 1986). The tyrosine residues in the tyrosine kinase domain gets phosphorylated due to the interaction between the ligand and the receptor. The role of IGF-1 in breast cancer has been proved by several clinical studies (Li et al., 2001; Michels and Willett, 2004). In recent years, the number of studies have been on the rise to elucidate the IGF1 function with breast cancer (Sarfestein et al., 2012; Becker et al., 2011; Kang et al., 2012). ERK and Akt were the two main pathways for IGF-1 receptor transduction (Le Roith et al., 2001; Jones and Clemmons, 1995; Menu et al., 2004). In one of the pathway, IGF-1 activates Raf and mitogen-activated protein kinase (MAPK) resulting in the transcription of proliferative genes whereas the second pathway involving phosphoinositide 3-kinase (PI3K)/ Akt is responsible for cell survival and signaling of anti-apoptosis (Manning and Cantley, 2007).

The significance of IGFs in growth regulation of breast cancer cell lines have been well studies. It also improves the cell survival rate of cancer cells. So, combining IGF inhibition with conventional cytotoxic drug treatment will have synergistic effect and enhance the breast cancer treatment. Pertuzumab was used with trastuzumab and docetaxel for patients having metastatic breast cancer with positive human epidermal growth factor receptor 2 (HER2) and without prior treatment (Baselga et al., 2012). Paclitaxel, a drug obtained from bark of Western yew tree is used for treating various 
cancers such as ovarian cancer, breast cancer, pancreatic cancer and lung cancer (Manfredi and Horwitz, 1984). Studies have shown that patients treated with paclitaxel for ovarian and breast cancer showed promising results (McGuire et al., 1989; Holmes et al., 1991). Most of the studies done before the clinical trials were based on growth inhibition assays (Rowinsky et al., 1990).

The effectiveness of drugs like trastuzumab, a monoclonal antibody used for treating breast cancer showed that targeting the receptors of growth factors will be useful (Slamon et al., 2001; Romond et al., 2005; PiccartGebhart et al., 2005). The action of combination therapy of paclitaxel and trastuzumab in breast cancer cell growth and division have not been studied. In this study, we investigated the cell cycle arrest and inhibition of cell proliferation by drug treatment was studied on estrogen receptor alpha positive $(\mathrm{ER}+)$ human breast cancer line, T47D and ER- human breast cancer cell line, Hs0578T.

\section{Materials and Methods}

\section{Materials}

All the chemicals and reagents used in this study were of pure and analytical grade. Paclitaxel (Tradename: TAXOL) and trastuzumab (Tradename: Herceptin) were purchase from Bristol Myers-Squibb Company (USA) and Roche (Switzerland) respectively. DMEM medium, FBS, trypsin-EDTA, PVDF membrane, antibiotics-antimycotics and PBS were acquired form Life Technologies (USA). Human IGF-1, HRP-conjugated rabbit anti-mouse IgG and goat anti-rabbit IgG secondary antibodies were purchased from SigmaAldrich (USA). Primary antibodies for IGF signaling molecules, proliferative cell nuclear antigen (PCNA), cMyc, p21 and cyclin, LY294002 and $\beta$-actin antibody were purchased from Cell Signaling Technology (CST) and Santa Cruz Biotechnology (USA).

\section{Cell lines and cell cultures}

The estrogen receptor alpha positive $(\mathrm{ER}+), \mathrm{T} 47 \mathrm{D}$ and estrogen receptor alpha negative (ER-), Hs0578T human breast cancer cell lines were obtained from American Type Culture Collection (USA). Both the cell lines were grown in DMEM with 10\% FBS, $2 \mathrm{mM}$ glutamine and antibiotics (penicillin $100 \mathrm{U} / \mathrm{mL}$ and streptomycin 50 $\mathrm{mg} / \mathrm{mL}$ ) at $37^{\circ} \mathrm{C}$ in a humidified $5 \% \mathrm{CO}_{2}$ in air atmosphere.

\section{Radioimmunoprecipitation and Western blot}

Cells were cultured in dishes containing growth medium at a density of $1 \times 10^{5}$ per dish overnight. The cells were washed twice with medium without serum and starved by incubating them in $5 \mathrm{~mL}$ of the same medium. After starvation, the cells were treated with DMSO (vehicle), $1 \mathrm{mM}$ paclitaxel and $5 \mathrm{mM}$ trastuzumab in 1:1 ratio for T47D cells and $5 \mathrm{mM}$ and $10 \mathrm{mM}$ at 1:2 ratio for Hs0578T cells. The drug combination effect between paclitaxel and trastuzumab was evaluated for the level of interaction (synergistic, additive or antagonistic), a method proposed by Chou (2006) was followed. The cells lysed after 24 hours of drug treatment by using radio immunoprecipitation assay (RIPA) buffer containing protease and phosphatase inhibitor cocktails. The protein concentration was determined by Lowry's method (Lowry et al., 1951). Fifty milligram of cell lysates were loaded in 12\% SDSPAGE and transferred to PVDF membrane. The membranes with transferred proteins were incubated with primary antibodies against IGF signaling molecules and $\beta$-actin in tris buffered saline. After incubation, the membranes were washed and incubated with HRP-conjugated with anti-mouse IgG in 1:5000 dilution and goat anti-rabbit IgG in 1:5000 dilution. The bands were visualized using the GE chemiluminescence (ECL) kit (GE Healthcare Life Sciences, New Jersey, USA).

\section{Growth factor, PI3K inhibitor and drug treatment}

Cells were cultured in dishes containing growth medium at a density of $1 \times 10^{5}$ per dish. After starving, the cells were pretreated with or without the growth factor, IGF-1 (50 ng/mL), $50 \mathrm{mM}$ of PI3K inhibitor, LY294002 for 1 hour in cell culture medium. After pretreatment, paclitaxel and trastuzumab were added at $1 \mathrm{mM}$ and 5 $\mathrm{mM}$ for T47D cells and $5 \mathrm{mM}$ and $10 \mathrm{mM}$ for Hs0578T cells respectively. After 24 hours, the intracellular proteins were obtained by cell lysis using RIPA buffer with protease and phosphatase inhibitor.

\section{Flow cytometry}

Cells were cultured in dishes containing growth medium at a density of $1 \times 10^{5}$ per dish. After starvation, it was treated with paclitaxel and trastuzumab at $1 \mathrm{mM}$ and $5 \mathrm{mM}$ for T47D cells and $5 \mathrm{mM}$ and $10 \mathrm{mM}$ for Hs0578T cells respectively and kept overnight. The cells were harvested with $0.25 \%$ trypsin and centrifuged at $3,000 \mathrm{xg}$ for $10 \mathrm{~min}$ and washed with PBS. Using $100 \%$ ice-cold methanol the cells were fixed overnight at $-20^{\circ}$ $\mathrm{C}$ and incubated with $50 \mathrm{mg} / \mathrm{mL}$ of propidium iodide in PBS and $1 \mathrm{mg} / \mathrm{mL}$ of ribonuclease in PBS for $30 \mathrm{~min}$. Cell cycle analyses was performed on FACSCanto II (BD Biosciences, USA). The cells without staining were used as a control. Data analysis was done using FlowJo version $X$ software.

\section{Statistical analysis}

Statistical analysis was done by one way ANOVA followed by multiple comparison by Fisher method using Stat View software (USA). The data were expressed as mean \pm SEM. 


\section{Results}

Down-regulation of IGF-1Rb, IRS-2, PI3K and upregulation of IGFBP-3 and PTEN by drug treatment

The important phenotypic characteristics of metastatic phase in breast cancer cells are regulated by IGF system which included survival, growth and metastasis (Figueroa and Yee, 1992). IGF-1Rb is one of the important proteins involved in IGF signaling in breast cancer cells.

Figure 1 shows the changes in IGF-1Rb level in both T47D and Hs0578T cell lines after the treatment with combination of paclitaxel and trastuzumab. The results showed that IGF-1Rb protein expression was appreciably lower after the drug treatment after 24 hours in both T47D and Hs0578T cell lines. The protein IGFBP-3 plays an essential role in controlling the IGFs in its mitogenic and anti-apoptotic effects by regulating their access to the IGF-1 receptor. IRS-2 and PI3K are the signaling molecules intracellularly in IGF pathway. PTEN negatively regulates PI3K/Akt and acts as a tumor suppressor. The results showed that expression of IGFBP-3 was higher after the combined treatment of paclitaxel and trastuzumab treatment and IRS-2 and PI3K protein expression levels were found to be lowered in treated cells. Interestingly the PTEN protein expression was markedly increased in the drug treated cells (Figure 1). Collectively, it can be said that synergistic effects of paclitaxel and trastuzumab reduced IGF-1 downstream molecules and increased the IGFNP-3 and PTEN protein levels. Hence, the combination of these two drugs have the potential to inhibit IGF-1 mediated proliferation of breast cancer cells used in this study.

\section{Western blot analyses}

Western blot was performed to find out the protein expressions of Mek, pERK 1 and 2, N-Ras, p38 and Raf1 in breast carcinoma since these are the main downstream signaling molecules during cell proliferation mediated by IGF-1. Figure 2 shows reduced expression of N-Ras, Mek, Raf- 1 and pERK 1 and 2 and elevated expression of p38 after drug treatment. Figure 3 shows the effect of PI3K inhibitor and combination of two drugs on the expression of pAkt protein. The function of Akt signaling is analyzed by using the well-characterized PI3K inhibitor, LY294002 as Akt protein helps in cell survival and breast cancer cells expresses pAkts.

Activation of cell lines with IGF-1 had elevated the pAkt protein expression and the pAkt expression was blocked by LY294002 as well as paclitaxel and trastuzumab treatment. Hence, the combined effect of IGF-1 and the two drugs were studied (Figure 3). The observed result supports that this combination also affects the Akt phosphorylation without affecting its total expression. Hence, the total Akt was used to normalize the pAkt expression level. Paclitaxel and trastuzumab treatment in the presence of inhibitors inhibited the Akt phosphorylation and reduced the survival rate of T47D and Hs0578T cells.

\section{Effect of paclitaxel and trastuzumab on expression of c- Myc and $\beta$-catenin}

The IGF-1 mediated cell proliferation has two downstream molecules, c-Myc and $\beta$-catenin. The effect of the two drugs, paclitaxel and trastuzumab on expression of c-Myc and $\beta$-catenin was studied in T47D and Hs078T cells. Figure 4 shows the results of paclitaxel and

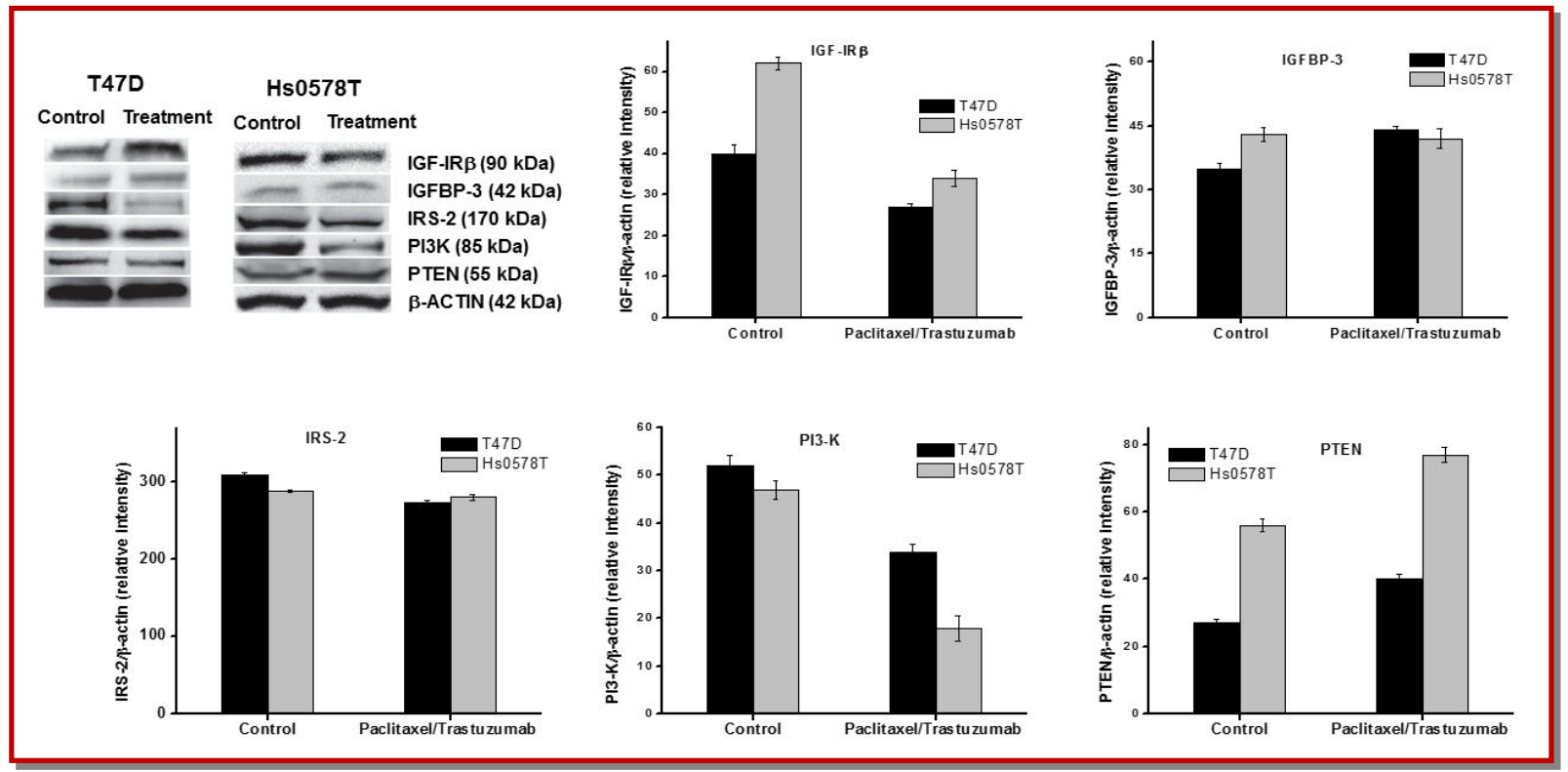

Figure 1: Effect of paclitaxel and trastuzumab on protein expression of downstream signaling molecules in IGF mediated cell proliferation in T47D and Hs0578T cells by Western blot 


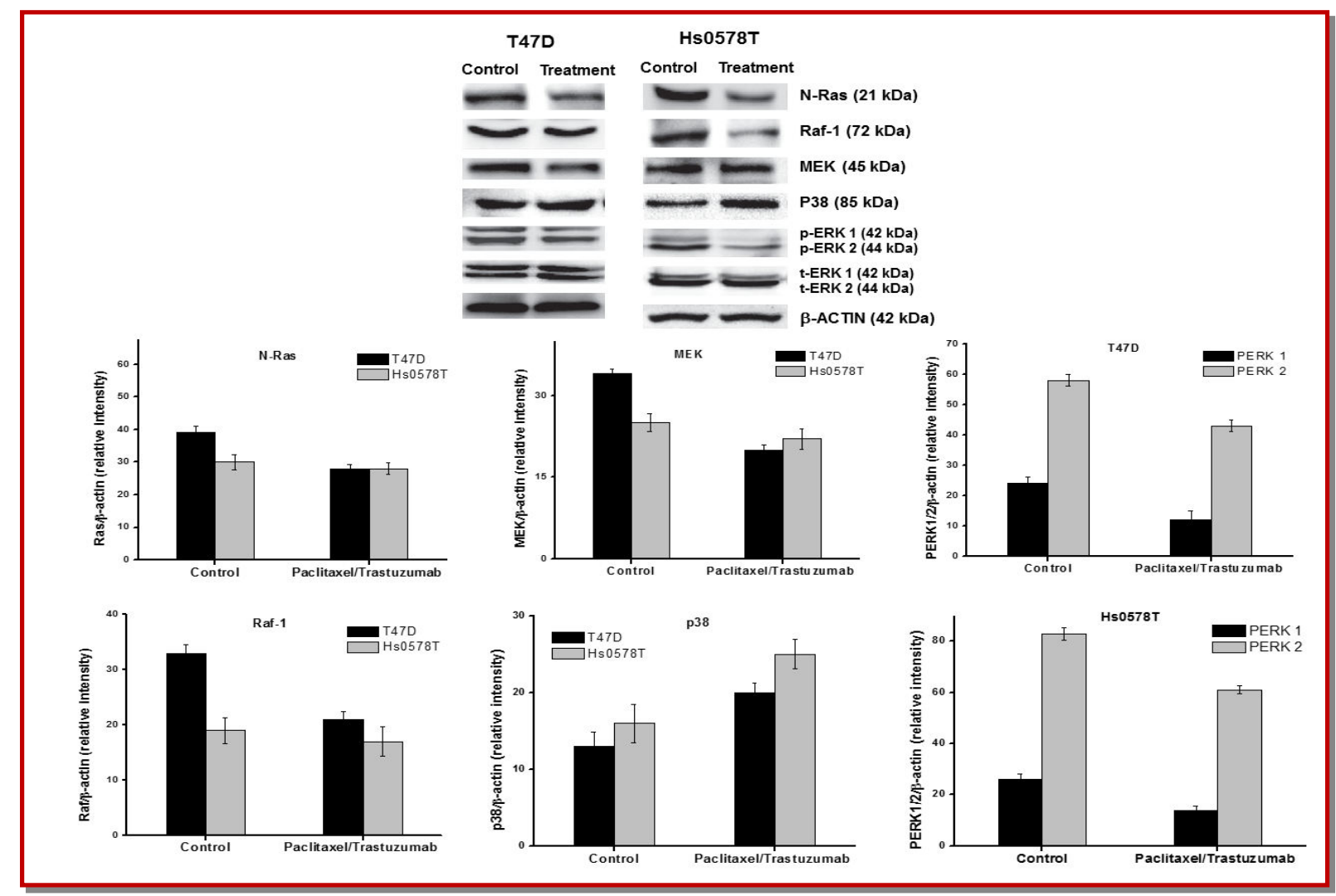

Figure 2: Effect of paclitaxel and trastuzumab treatment on various protein expression in MAPK pathway in T47D and Hs0578T cells

trastuzumab effect. We observed decrease in c-Myc and $\beta$-catenin expression after the drug treatment in both T47D and Hs078T cells.

\section{Cell cycle analyses}

Figure 5 shows increase in number of cells in the G0/ G1 phase after the drug treatment in the T47D and Hs078T cell lines. The treatment showed 66 and 53\% in T47D and Hs0578T cells respectively in G0/G1 phase. Compared with vehicle treated cells, there was rise in dead cells by $7.6 \%$ and $9.7 \%$ in T47D and Hs0578T cells respectively. Drug-induced cell growth inhibition was the main reason for the changes in the expression of cell cycle regulatory proteins.

Figure 6 indicates the decreased levels of various cyclins upon paclitaxel and trastuzumab treatment since cyclins are most important for the cells to go through various stages of cell cycle and alteration in the cyclin expression depicts the cell cycle after the drug treatment. P21 level was found to be markedly increased in drug treated T47D and Hs0578T cells since it is an inhibitor to potent cyclin dependant kinase (CDK) involved in cyclin-CDK binding and thereby preventing its catalytic activity and paving the way for cell cycle arrest.

\section{Discussion}

In this study, we report about the synergistic effect of paclitaxel and trastuzumab and their action on the survival of ER+ and ER- breast cancer cell lines. This was based on the IGF-1 signaling and their role in breast cancer has been supported by several clinical studies (Figueroa and Yee, 1992; Papa et al., 1993; Resnik et al., 1998; Li et al., 2001; Michels and Willet, 2004; Lu et al., 2001). Targeting the pathway of IGF-1R can be promising in developing new therapies for breast cancer treatment. We observed that the combined paclitaxel and trastuzumab distinctly prevented proliferation of cells as evident from their $\mathrm{IC}_{50}$ values. After 24 and 48 hours, $\mathrm{IC}_{50}$ values were 6 and $3.7 \mathrm{mM}$ for T47D cells and 7 and $5.2 \mathrm{mM}$ for Hs0578T cells respectively.

IGFBP-3 is a major IGF binding protein showed competitive inhibition towards IGF action. The IGF inhibition activates caspases involved in cell death and causes apoptosis and prevents proliferation independent of IGF (Kim et al., 2004). This study indicates that reduced expression of IGF-1Rb and higher expression of IGFBP-3 drug treated cells. The tyrosine kinase domain residues in the $\beta$-subunit are autophospho- 


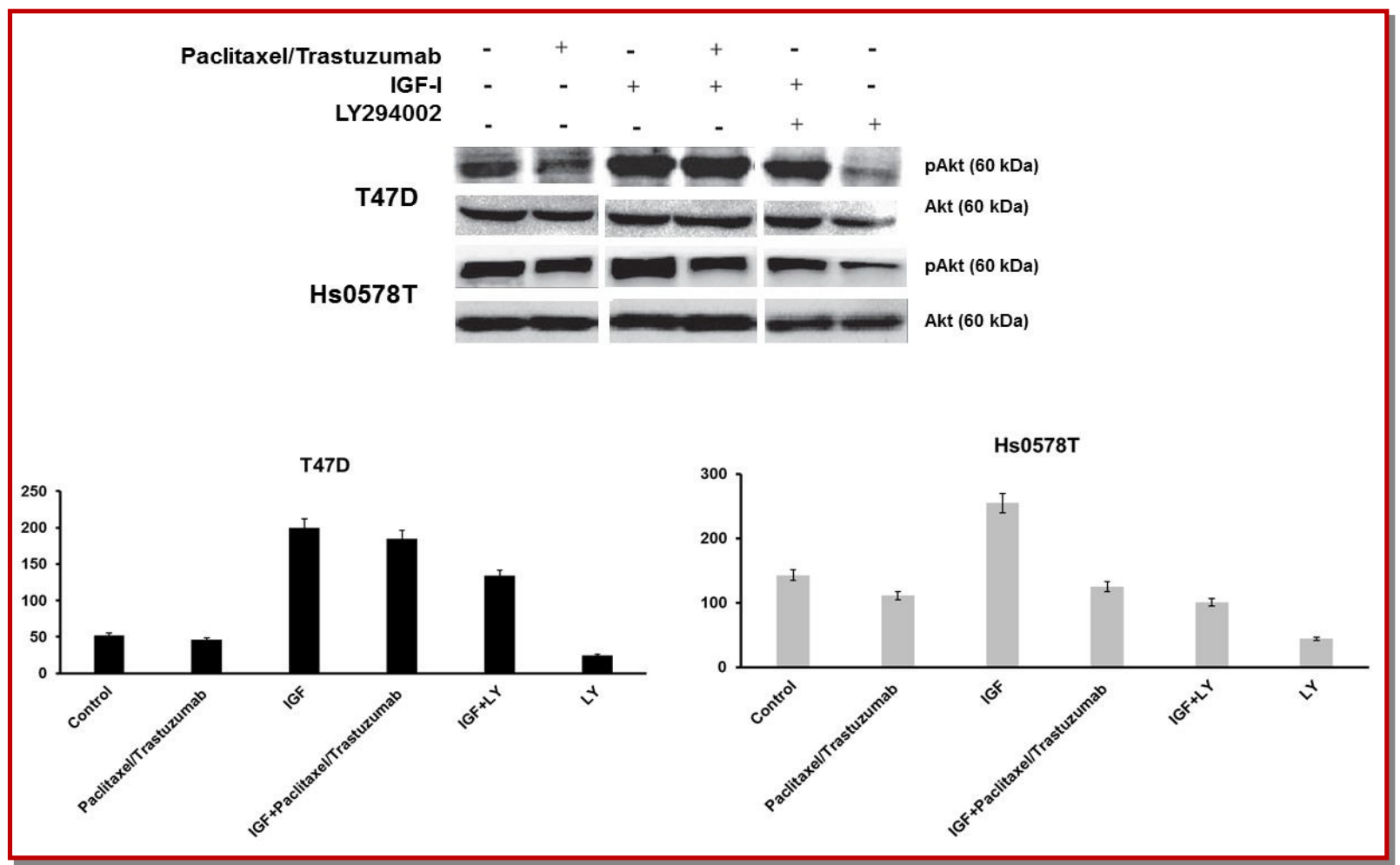

Figure 3: pAkt protein expression in T47D and Hs0578T cells treated with paclitaxel and trastuzumab and induced by IGF-1 and inhibited by LY294002

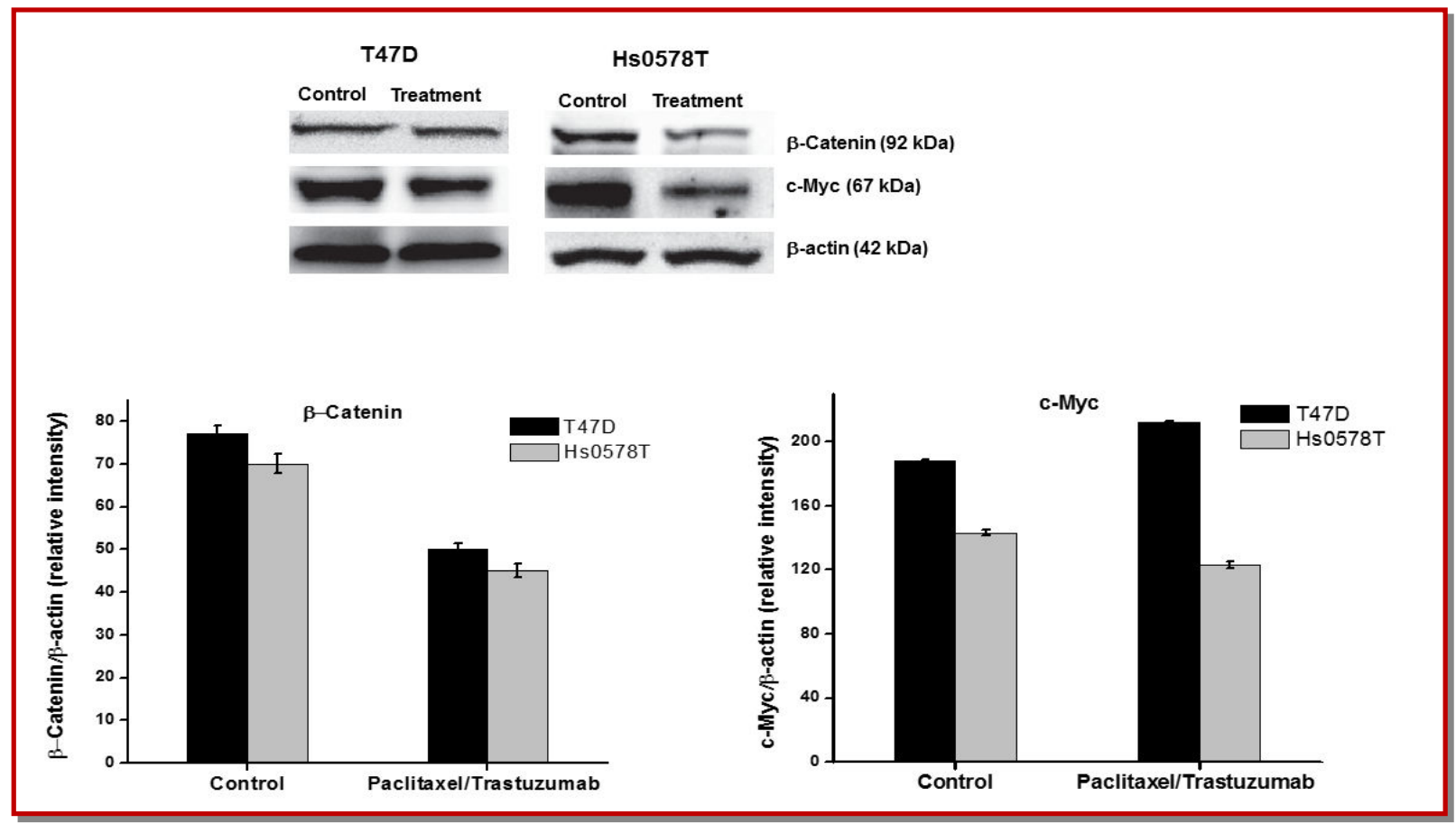

Figure 4: Effect of paclitaxel and trastuzumab in expression of proteins c-Myc and b-catenin in IGF-1 mediated cell proliferation

rylated during the ligand interaction with IGF-1R. Other phosphorylation sites function as a docking site for IRS facilitating through the PI3K subunit regulation. The receptor can also activate the MAPK pathway by recruiting SHC. The expression of Raf, IRS-2, PI3K and Ras proteins were reduced drug treated cells. PTEN is a tumor suppressor and most commonly mutated protein. The combination of paclitaxel and trastuzumab 


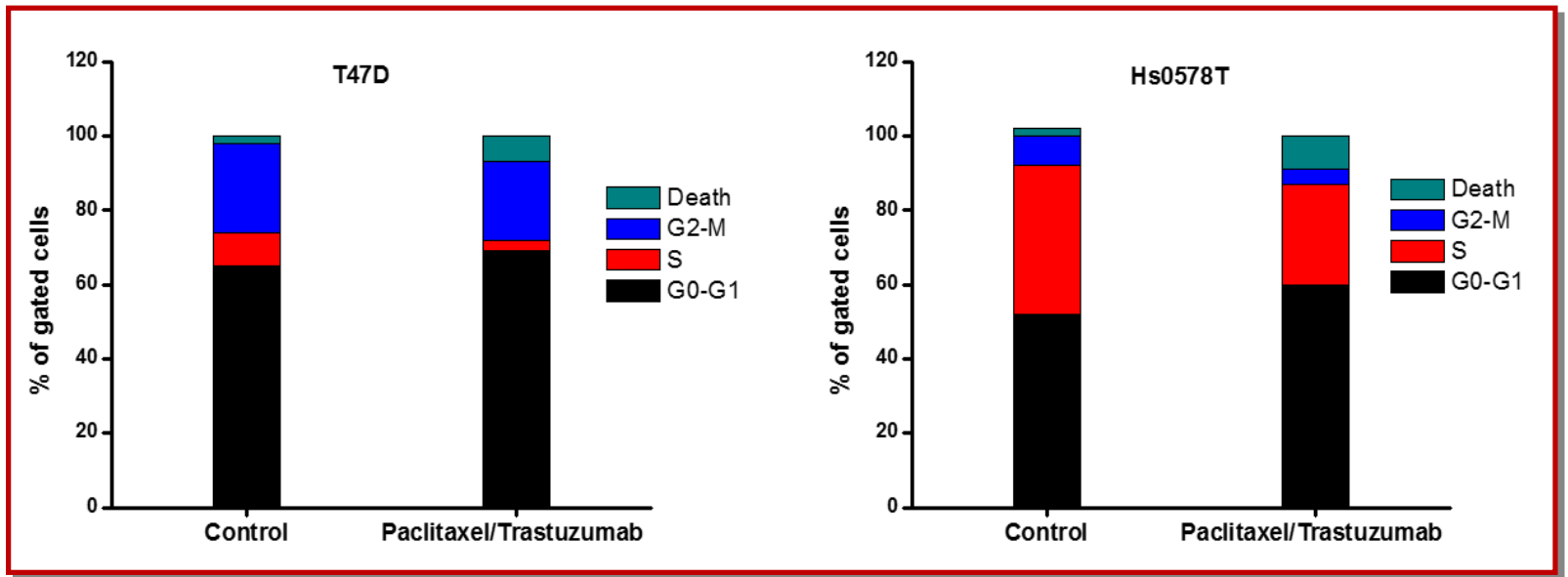

Figure 5: Cell cycle analysis of paclitaxel and trastuzumab treated T47D and Hs0578T cells. Total cell population was taken in to account to calculate number of cells in each cell cycle phase

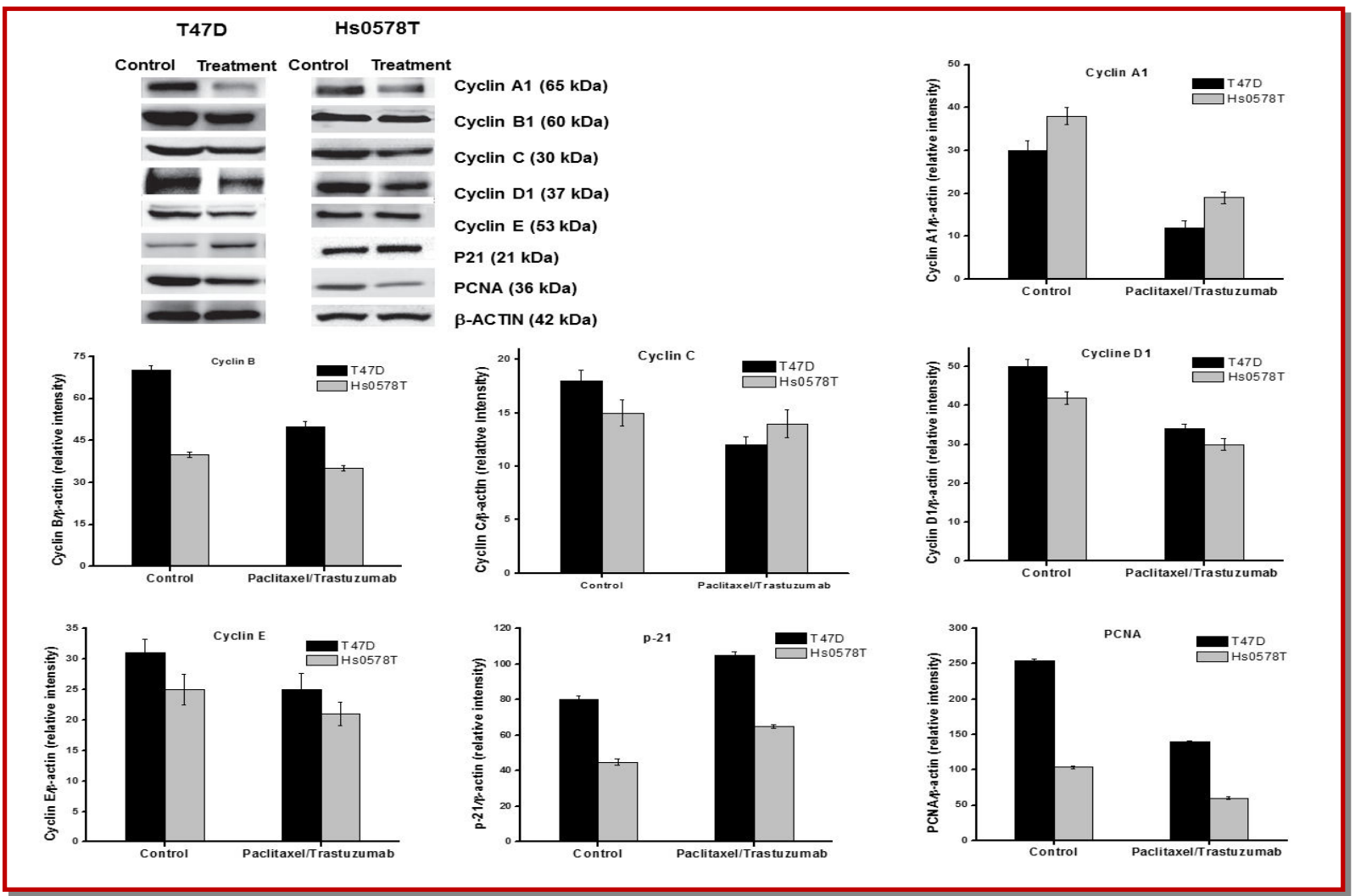

Figure 6: The expression of cyclins in paclitaxel and trastuzumab treated breast cancer cell lines analyzed by immunoblot

showed PTEN expression in both cell lines were found to be increased. We studied the role of Akt in cell growth and cell deaths in ER+ and ER- breast cancer cell lines by using PI3K inhibitor, LY294002. The mechanism of Akt inhibition by drug treatment was studied by first inducing the proliferation of both the cells lines by IGF-1 and then blocked by LY294002. The experimental results showed that both the drugs and the inhibitor reduced the expression of pAkt in breast cancer lines induced by IGF-1. This result highlighted the need of PI3K/Akt pathway in cell growth. In addition the down regulation of c-Myc and $\beta$-catenin accumulation was also found in the cells treated with drug.

The combination of paclitaxel and trastuzumab regulates the MAPK pathway as evident by the altered protein expression of MEK, ERK 1 and 2 and p38 in both T47D and Hs0578T cells. This was corroborated by i) down-regulation of MEK and pERK 1, 2 and upregulation of p38 in both the cell lines upon drug treatment; ii) decrease in ERK 1, 2 activation in cells 
treated with paclitaxel and trastuzumab; iii) increase in G0/G1 population in T47D cells and noticeable changes in Hs0578T cells (based on the accumulation, apoptotic cells were observed); iv) decreased cyclin levels upon drug treatment; (v) increase in p21 level upon paclitaxel and trastuzumab treatment; vi) reduced PCNA expression after drug treatment. These results showed that paclitaxel and trastuzumab treated cells induced apoptosis.

\section{Conclusion}

The combined paclitaxel and trastuzumab treatment potentially inhibited the growth of both T47D and Hs0578T cells by down regulating IGF signaling molecules. Further, combination of paclitaxel and trastuzumab acts as an inhibitor of IGF-1R/Akt/ERK signaling. These inhibition in growth was due to the accumulation of G0/G1 cells and reduced expression of cyclin proteins. Thus the combined drugs can serve as an promising candidates for breast cancer treatment.

\section{References}

Baselga J, Cortés J, Kim SB, Im SA, Hegg R, Im YH, Roman L, Pedrini JL, Pienkowski T, Knott A, Clark E, Benyunes MC, Ross G, Swain SM; CLEOPATRA Study Group. Pertuzumab plus trastuzumab plus docetaxel for metastatic breast cancer. N Engl J Med. 2012; 366: 109-19.

Becker MA, Ibrahim YH, Cui X, Lee AV, Yee D. The IGF pathway regulates ERa through a S6K1-dependent mechanism in breast cancer cells. Mol Endocrinol. 2011; 25: 516-28.

Chou TC. Theoretical basis, experimental design, and computerized simulation of synergism and antagonism in drug combination studies. Pharmacol Rev. 2006; 58: 621-81.

Figueroa JA, Yee D. The insulin-like growth factor binding proteins (IGFBPs) in human breast cancer. Breast Cancer Res Treat. 1992; 22: 81-90.

Holmes FA, Walters RS, Theriault RL, Forman AD, Newton LK, Raber MN, Buzdar AU, Frye DK, Hortobagyi GN. Phase II trial of taxol, an active drug in the treatment of metastaatic breast cancer. J Natl Cancer Inst. 1991; 83: 1797-805.

Jones JI, Clemmons DR. Insulin-like growth factors and their binding proteins: Biological actions. Endocr Rev. 1995; 16: 334 .

Kang HJ, Yi YW, Kim HJ, Hong YB, Seong YS, Bae I. BRCA1 negatively regulates IGF-1 expression through an estrogenresponsive element-like site. Cell Death Dis. 2012; 3: e336.

Kim HS, Ingermann AR, Tsubaki J, Twigg SM, Walker GE, Oh Y. Insulin-like growth factor binding protein 3 induces caspase dependent apoptosis through a death receptormediated pathway in MCF7 human breast cancer cells. Cancer Res. 2004; 64: 2229-37.

Le Roith D, Bondy C, Yakar S, Liu J. The somatomedin hypothesis: 2001. Endocr Rev. 2001; 22: 53-74.
Li BD, Khosravi MJ, Berkel HJ, Diamandi A, Dayton MA, Smith M, Yu H. Free insulin like growth factor I and breast cancer risk. Int J Cancer. 2001; 91: 736-39.

Lowry OH, Rosebrough NJ, Farr AL, Randall RJ. Protein measurement with the Folin phenol reagent. J Biol Chem. 1951; 193: 265-75.

Lu Y, Zi X, Zhao Y, Mascarenhas D, Pollak M.Insulinlike growth factorI receptor signaling and resistance to trastuzumab (Herceptin). J Natl Cancer Inst. 2001; 93: 185257.

Manfredi JJ, Horwitz SB. Taxol: An antimitotic agent with a unique mechanism of action. Pharmacol Ther. 1984; 25: 83125.

Manning BD, Cantley LC. AKT/PKB signaling: Navigating downstream. Cell 2007; 129: 1261-74.

McGuire WP, Rowinsky EK, Rosenshein NB, Grumbine FC, Ettinger DS, Armstrong DK, Donehower RC. Taxol: A unique antineoplastic agent with significant activity in advanced ovarian epithelial neoplasms. Ann Intern Med. 1989; 111: 273-79.

Menu E, Kooijman R, Van Valckenborgh E, Asosingh K, Bakkus M, Van Camp B, Vanderkerken K. Specific roles for the PI3K and the MEK-ERK pathway in IGF-1-stimulated chemotaxis, VEGF secretion and proliferation of multiple myeloma cells: Study in the 5T33MM model. Br J Cancer. 2004; 90: 1076-83.

Michels KB, Willett WC. Breast cancer-early life matters. N Engl J Med. 2004; 351: 1679-81.

Nielsen TO, Andrews HN, Cheang M, Kucab JE, Hsu FD, Ragaz J, Gilks CB, Makretsov N, Bajdik CD, Brookes C, Neckers LM, Evdokimova V, Huntsman DG, Dunn SE. Expression of the insulin like growth factor I receptor and urokinase plasminogen activator in breast cancer is associated with poor survival: Potential for intervention with 17-allylamino geldanamycin. Cancer Res. 2004; 64: 286-91.

Papa V, Gliozzo B, Clark GM, McGuire WL, Moore D, FujitaYamaguchi Y, Vigneri R, Goldfine ID, Pezzino V. Insulin-like growth factor I receptors are overexpressed and predict a low risk in human breast cancer. Cancer Res. 1993; 53: 373640 .

Piccart-Gebhart MJ, Procter M, Leyland-Jones B, Goldhirsch A, Untch M, Smith I, Gianni L, Baselga J, Bell R, Jackisch C, Cameron D, Dowsett M, Barrios CH, Steger G, Huang CS, Andersson M, Inbar M, Lichinitser M, Láng I, Nitz U, Iwata H, Thomssen C, Lohrisch C, Suter TM, Rüschoff J, Suto T, Greatorex V, Ward C, Straehle C, McFadden E, Dolci MS, Gelber RD; Herceptin Adjuvant (HERA) Trial Study Team. Trastuzumab after adjuvant chemotherapy in HER2-positive breast cancer. N Engl J Med. 2005; 353: 1659-72.

Resnik JL, Reichart DB, Huey K, Webster NJ, Seely BL. Elevated insulin-like growth factor I receptor autophosphorylation and kinase activity in human breast cancer. Cancer Res. 1998; 58: 1159-64.

Romond EH, Perez EA, Bryant J, Suman VJ, Geyer CE Jr, Davidson NE, Tan-Chiu E, Martino S, Paik S, Kaufman PA, Swain SM, Pisansky TM, Fehrenbacher L, Kutteh LA, Vogel VG, Visscher DW, Yothers G, Jenkins RB, Brown AM, Dakhil SR, Mamounas EP, Lingle WL, Klein PM, Ingle JN, Wolmark 
N. Trastuzumab plus adjuvant chemotherapy for operable HER2-positive breast cancer. N Engl J Med. 2005; 353: 167384 .

Rowinsky EK, Cazenave LA, Donehower RC. Taxol: A novel investigational antimicrotubule agent. J Natl Cancer Inst. 1990; 82: 1247-59.

Sachdev D, Hartell JS, Lee AV, Zhang X, Yee D. A dominant negative type I insulin-like growth factor receptor inhibits metastasis of human cancer cells. J Biol Chem. 2004; 279; 5017-24.

Sarfstein R, Pasmanik-Chor M, Yeheskel A, Edry L, Shomron N, Warman N, Wertheimer E, Maor S, Shochat L, Werner H.
Insulin-like growth factor-I receptor (IGF-IR) translocates to nucleus and autoregulates IGF-IR gene expression in breast cancer cells. J Biol Chem. 2012; 287: 2766-76.

Slamon DJ, Leyland-Jones B, Shak S, Fuchs H, Paton V, Bajamonde A, Fleming T, Eiermann W, Wolter J, Pegram M, Baselga J, Norton L. Use of chemotherapy plus a monoclonal antibody against HER2 for metastatic breast cancer that overexpresses HER2. N Engl J Med. 2001; 344: 783-92.

Ullrich A, Gray A, Tam AW, Yang-Feng T, Tsubokawa M, Collins C, Henzel W, Le Bon T, Kathuria S, Chen E. Insulinlike growth factor I receptor primary structure: Comparison with insulin receptor suggests structural determinants that define functional specificity. EMBO J. 1986; 5: 2503-12. 